\title{
ИРКУТСКИЙ ХУДОЖЕСТВЕННЫЙ МУЗЕЙ: ЖИЗНЬ В ГОРОДЕ
}

\author{
Н. С. Сысоева ${ }^{1}$, М. Л. Ткачева \\ ${ }^{1}$ Государственное бюджетное учреждение культуры «Иркутский областной художественный музей \\ им. В. П. Сукачева", г. Иркутск, Российская Федерация \\ ${ }^{2}$ Байкальский государственный университет, г. Иркутск, Российская Федерация
}

\author{
Информация о статье \\ Дата поступления \\ 10 января 2018 г. \\ Дата принятия к печати \\ 28 февраля 2018 г. \\ Дата онлайн-размещения \\ 30 марта 2018 г. \\ Ключевые слова \\ Иркутский областной \\ художественный музей \\ им. В. П. Сукачева; выставочные \\ проекты; музейное развитие; \\ художественное восприятие; \\ художественная форма; \\ Даши Намдаков
}

\begin{abstract}
Аннотация
Дается общая характеристика деятельности и стратегии развития Иркутского художественного музея. Формулируются задачи по внедрению новых практик в музейную деятельность. Подчеркивается значение систематической работы по воспитанию художественного вкуса и художественных пристрастий публики, постоянно действующих программ для разновозрастных категорий посетителей. Анализируются выставочные проекты Даши Намдакова в ИОХМ с точки зрения восприятия публикой. Характеризуется художественная форма скульптуры и ее роль в художественном восприятии.
\end{abstract}

\section{IRKUTSK FINE ARTS MUSEUM: LIFE IN THE CITY}

\author{
Natalia S. Sysoeva ${ }^{1}$, Marina L. Tkacheva² \\ ${ }^{1}$ State Budgetary Institution of Culture "Vladimir Sukachev Irkutsk Regional Fine Arts Museum», Irkutsk, \\ the Russian Federation \\ ${ }^{2}$ Baikal State University, Irkutsk, the Russian Federation
}

\section{Article info}

Received

January 10, 2018

Accepted

February 28, 2018

Available online

March 30, 2018

\section{Keywords}

Vladimir Sukachev Irkutsk

Regional Fine Arts Museum;

exhibition projects; museum

development; artistic

perception; artistic form;

Dashi Namdakov

\begin{abstract}
The article is dedicated to the general overview of activities and development strategies of Irkutsk Fine Arts Museum. The authors formulate the tasks of introducing new practices into museum work. They stress the importance of systematic work in the education of the artistic taste and artistic preferences of the public, as well as the importance of ongoing programs for different age categories of visitors. The exhibition projects of Dashi Namdakov held in Irkutsk Fine Arts Museum are analyzed from the point of view of the audience perception. The authors examine the sculpture as an art form and its role in artistic perception.
\end{abstract}

Цель работы Государственного бюджетного учреждения культуры «Иркутский областной художественный музей им. В. П. Су- качева» - способствовать развитию музейного дела и создать условия для превращения его в значимый ресурс развития общества и 
культуры региона. Перспективные планы работы музея ориентированы на реализацию новых практик, рассчитанных:

- на использование внешней среды как главного источника ресурсов и фракторов развития музея;

- активное внедрение в работу музея современных инорормационных и коммуникационных технологий;

- внедрение электронных экспозиций и виртуальных отделов, специализированных и монотематических экспозиций;

- широкое внедрение интерактивных форм работы, анимации и игровых технологий и, как следствие, изменение пропорций между образовательной и развлекательной составляющими работы с посетителями;

- укрепление и развитие музея как уникального крупного музейного комплекса, объединяющего художественную и мемориально-историческую среду и в процессе своего развития формирующего качественно новое пространство для коммуникаций, для производства и реализации новых идей и проектов.

Музей представляет собой целый комплекс исторических зданий и парков, расположенных в памятниках истории и культуры XIX в. Вместе они образуют систему многофункциональных помещений и фондов, объединяющих административный, финансово-экономический, реставрационно-хранительский, экспозиционно-выставочный, историко-мемориальный, информационно-образовательный, производственный блоки и службу безопасности.

ИОХМ принадлежит музейной сети Иркутской области, лидерами которой, наряду с ИОХМ, являются Иркутский областной краеведческий музей, архитектурно-этнографический музей «Тальцы», Иркутский областной историко-мемориальный музей декабристов. Их объединение позволяет использовать фонды и ресурсы всех музеев для организации совместных экспозиций.

Долгое время музеем проводились исследования сибирского искусства, которые позволили в 1995 г. открыть отдел сибирского искусства сначала в памятнике архитектуры XVIII в. "Собор Богоявления», а затем на ул. Карла Маркса, 23-25. В России тогда это был первый опыт. С учетом высокого качества коллекции, ее разнообразия, высокой художественной ценности стало возможно образование отделов сибирского искусства, его широкое экспонирование и пропаганда. Особое значение для города имеет коллекция и экспонирование работ современных иркутских художников, которые объединяют традиции иркутской художественной школы и представляют современное видение изобразительной культуры.

Помимо традиционной работы, заключающейся в пополнении, репрезентации и сохранении музейных коллекций, коллектив работает над модернизацией музейного пространства и внедрением новых технологий. Расширение выставочных площадей позволило бы разнообразить формы работы с посетителями, осуществить инновационные проекты, создать бо́льшую комфортность для пребывания гостей музея, организовать депозитарий, основанный на принципах открытого хранения фондов.

Естественно, что о работе музея горожане судят по тем выставкам и программам, которые организованы для посетителей, подразделяющихся на две большие группы. Первая - это гости города, которые приходят, чтобы познакомиться с коллекцией, с шедеврами, находящимися в собрании. Вторая - это местные жители, которые посещают в основном временные выставки, смотрят произведения современных художников, а также работы, которые бо́льшую часть времени находятся в запасниках музея.

Сотрудниками разработана программа, ориентированная на детскую и юношескую аудиторию. Тематические адаптированные экскурсии для школьников по постоянной экспозиции и временным выставкам дополняются учебно-познавательной программой и проведением мастер-классов. Кроме того, музеем активно осваиваются новые формы работы с посетителями. Увлекательным времяпрепровождением, интересным и детям, и их родителям, становятся музейные квесты. Сторителлинг - сочинение истории по картине - еще одна фрорма перехода от пассивного восприятия к активному творческому соучастию, собственной интерпретации картины и эмоциональной реакции на нее. Это чрезвычайно увлекательный и познавательный процесс, ведь каждый человек обладает своим особенным жизненным опытом, тонкостью восприятия, темпераментом и интеллектом. И в результате в сторителлинге участвуют люди самого разного возраста, что мы наблюдаем во время проведения «Ночи искусств», уже несколько лет регулярно проходящей в музее.

В настоящее время развернут процесс модернизации музейно-педагогической деятельности, в котором особый акцент делается на изменение роли человека в музейной системе. Из просто посетителя он превра- 
щается в полноправного участника, соратника и партнера, и с этим связана идеология «открытого музея», строящего свою работу на развитии интерактивных форм, анимации, сотворчества и внедрения. Они основаны на принципах открытости традиционных форм работы (хранение, исследование, реставрация). Именно в них перспектива развития сотрудничества музея и его посетителя, в том числе совместной творческой работы над проектами, над выработкой новых идей и их реализацией.

Конкретные события музейной жизни ярко демонстрируют также ресурсы достаточно традиционных форм музейной экспозиции. Такими событиями стали выставки Даши Намдакова, уже несколько раз проходившие в ИОХМ. Следует заметить, что успех его выставок дал толчок для частных инициатив (выставки в галерее В. Бронштейна). Но профессионально сделанные в художественном музее экспозиции заслуживают отдельного анализа. Они вызывали неподдельный интерес и волну отзывов, которые могут стать предметом специального упоминания и анализа именно с точки зрения эволюции сознания публики.

Когда-то Гегель писал, что произведение искусства - не кактус, что увядает в безлюдных лесах, не вызывая ни в ком восхищения. Оно имеет своей целью существовать лишь для нашей души и духа; оно по существу своему является «вопросом, обращенным к откликающемуся на него сердцу, воззванием к душам и умам» [1, с. 27]. Произведение искусства, хотя и образует "согласующийся в себе завершенный мир», все же существует «не для себя, а для нас, для публики...». Bсе персональные выставки Намдакова (а их в разных музеях Иркутска было уже около десяти) сопровождались многочисленными откликами. Книги отзывов, в которых предлагается оставлять свои впечатления от экспозиции, как правило, заполняются до последней страницы. Эти реплики объединяет одно: иркутяне снова осознали себя активными и сочувствующими свидетелями поисков и достижений выдающегося художника. Публика привыкает к высококлассной скульптуре; незаметное движение массового вкуса - самый большой, реальный и положительный результат, которого можно достичь только средствами высокопрофессионального творчества.

Более утонченные и искушенные зрители «проговариваются» о своих впечатлениях, раскрывая важные черты творчества и работ скульптора. Поскольку книга отзывов предмет публичный, мы позволим себе при- вести некоторые записи (исправлена только грамматика).

«Персонажи из другого мира, равнозначного тому, где мы сейчас. То есть не кажутся странными. Просто другими, а легко принимаются как данность...»

«Глубина человеческого подсознания и еще что-то...»

«Страшновато все это...»

«Какое удивительное сочетание этничного и всемирного! Великим народ делают его лучшие представители. Нет, не так. Его гении. Спасибо Бурятии...»

«Мы обижены на служительниц: они не разрешали потрогать скульптуры пальцами...» «Они только кажутся страшными, а вообще хочется по ним полазить...» (из разговора с маленькой девочкой). «Хочется все потрогать... и принять позы, жаль, люди вокруг. Творчество такое нельзя воспринимать головой, никак не получится...» «Табличка «Руками не трогать!» А как хочется гладить ее прикасаться к ней, обнять. Никогда прежде такого ощущения от скульптуры не получала...» «Вы «искупали» нас в пластике, ощущении формы и движения. Великолепно, мощно, с юмором!» «Большая внутренняя сила, но прячется глубоко. Кажется, что пальцами достать ее проще...»

«Впервые на вашей выставке (с третьего раза) ощутил юмор в ваших работах, особенно в воинах...»

«Из всех работ мне больше всего понравился «Большой человек» (папа говорит, что он медитирует), он мне понравился своей необычностью, своими большими формами, задумчивостью (речь идет о скульптуре «Медитация». - Авт.). А в быке-воине («Мистерия») мне понравился щит со змеей, интересные доспехи, ха-ха, и плавки, он совсем не страшный. Скульптура «Воспоминание» напоминает больше болезнь. По фильму было сказано, что вы семь лет болели. Хорошо, что вы выздоровели. А из графических работ мне больше понравился воин с саблей и со стрелами. Он мне понравился тем, что он был, на мой взгляд, смелый и веселый. Я желаю вам счастья, любви и, конечно же, здоровья. Ульяна, 12 лет».

«Мне больше всего понравилось то, что автор выбирает очень хорошие сочетания, такие как мальчик на коте, мадонна с птичкой. Лиза, 10 лет».

«Когда-то меня поразили объемные бедра и тонкая голень скульптур. Пришла домой, разделась и посмотрела в зеркало - это была я. Замечательно схваченная деталь!..» «Очень содержательные скуль- 
птуры. Где узнаешь много знакомых людей с их состояниями, жизнеощущениями, восприятием. Иногда это восторг от увиденного, иногда трогательное, нежное желание уберечь истинную любовь...» «Увидела своего сына... лет назад... А кот, напротив, вырос. Метаморфозы...»

«В полной мере представлена философия Востока, - это и живая жизнь, и символика. Думаю, что Даши - гений. И его имя соединит нас с будущим...»

Любое художественное восприятие начинается с непосредственного впечатления, продолжается осознанием значимости формы, материала, которые естественным образом и начинают, и завершают художественное произведение. Красота - произведение духа и нуждается в разработанной технике: «Только после многосторонних опосредствований удается преодолеть разнообразное, пестрое, запутанное, чрезмерное, тягостное и в этой победе спрятать и уничтожить всю подготовительную работу, так что теперь кажется, будто свободная красота возникла совершенно беспрепятственно, как из одного слитка» [2, с. 9]. В вещах, созданных Даши, поражает чистота мастерства и требовательность художника. К какой бы области искусства Намдаков ни прикоснулся, будь то чеканка или графика, парковая скульптура или ювелирная подвеска, он демонстрирует виртуозную технику. Создается впечатление, что он намеренно ищет наиболее трудные приемы. Он осваивает новые технологии изготовления украшений, участвует - впервые для него в создании монументального кинофильма и даже в традиционных рисунке и скульптуре выбирает путь наибольшего сопротивления. Блестящее мастерство связывает Намдакова с художественной традицией «старых мастеров» XX в., заключающейся в высоком профессионализме и владении разнообразными умениями, в том числе чисто ремесленными. Его постоянная работа видна и в качестве изделий, и в их количестве. В том, что он делает, Намдаков не допускает ни лишней или небрежной линии, ни лишнего объема. Необходимость, уместность, «вылизанность» формы - то, что отличает его творчество. Но «вылизанность» его скульптур - не только индивидуальная требовательность, перфекционизм художника. Утонченность отделки указывает на связь скульптуры со сорерой перцептивно-тактильного; отсюда идет почти непреодолимое стремление трогать, гладить, ощупывать скульптуру. У скульптур Даши есть миссия: с их помощью окультуриваются, художественно обрабатываются и воспитываются наши тактильные ощущения, прибавляя к наслаждению от прекрасной формы и наслаждение от соприкосновения - действительного или желаемого - с поверхностью предмета. В сегодняшнем виртуально-созерцательном мире его статуи утверждают ценность плотной, материальной поверхности, без восприятия которой невозможно проникнуть в суть формы. Даши объясняется с миром не с помощью слов, но с помощью предметов, из которых выстраивается иерархия значений. В этой иерархии то, что сохраняется, не изменяя формы, имеет наивысшую ценность, ибо прошло экспертизу на устойчивость во времени, доказало универсальность использования в жизни, следовательно, достойно сохранения, выживет и в будущем.

Намдаков - аристократ в своем искусстве. Серебро, бронза, красное дерево, золото, драгоценные камни - вот его любимцы. Изысканность и щедрость ювелирных украшений делают их чрезвычайно востребованными категорией состоятельных и одновременно художественно воспитанных потребителей.

Безупречность скульптурной формы позволяет с легкостью «переступить» границу искусства и повседневности, максимально сократить естественную зрительскую установку дистанцированного восприятия работ Намдакова.

Для такого перфекциониста, как Намдаков, естественно ощущать себя частью сегодняшнего художественного авангарда во всем. Еще на первой выставке стало понятно, что мастер не терпит дешевки в используемом сырье и халтуры в исполнении заказов. Его высокая требовательность созвучна наисовременнейшим представлениям о сущности художественного производства. Свыкнуться с дороговизной искусства - это вопрос не посторонний для серьезного профессионала. Вот почему встреча с итальянскими мастерами-отливщиками оказалась обогащающей и ускорила вхождение мастера в мировой художественный процесс, а встречи со зрителями заканчиваются неизменно восторженными откликами и рецензиями.

\section{СПИСОК ИСПОЛЬЗОВАННОЙ ЛИТЕРАТУРЫ}

1. Гегель Г. В. Ф. Эстетика : в 4 т. / Г. В. Ф. Гегель. - М. : Искусство, 1968. - Т. 1. - 312 с.

2. Гегель Г. В. Ф. Эстетика : в 4 т. / Г. В. Ф. Гегель. - М. : Искусство, 1971. - Т. 3. - 620 с. 


\section{REFERENCES}

1. Hegel G. W. F.; Glockner H. (Hrsg.). Samtliche Werke. Jubilaumsausgabe in zwanzig Banden. Bd. 1-14. Vorlesungen über die Ästhetik. Stuttgart, 1927-1940. (Russ. ed. Hegel G. W. F. Estetika. Moscow, Iskusstvo Publ., 1968. Vol. 1. 312 p.).

2. Hegel G. W. F.; Glockner H. (Hrsg.). Samtliche Werke. Jubilaumsausgabe in zwanzig Banden. Bd. 1-14. Vorlesungen über die Ästhetik. Stuttgart, 1927-1940. (Russ. ed. Hegel G. W. F. Estetika. Moscow, Iskusstvo Publ., 1968. Vol. 3. 620 p.).

\section{Информация об авторах}

Сысоева Наталья Сергеевна - доцент, директор ГБУК «ИОХМ им. В. П. Сукачева», председатель Иркутского регионального отделения ВТОО «Союз художников России», 664025, Иркутск, ул. Ленина, 5, e-mail: iohm@irk.ru.

Ткачева Марина Львовна - кандидат фолософских наук, доцент, кафедра философии, Байкальский государственный университет, 664003, г. Иркутск, ул. Ленина, 11, e-mail: margo514@уandex.ru.

\section{Для цитирования}

Сысоева Н. С. Иркутский художественный музей: жизнь в городе / Н. С. Сысоева, М. Л. Ткачева / / Известия Байкальского государственного университета. - 2018. - T. 28, № 1. - C. 138-142. - DOI: $10.17150 / 2500-2759.2018 .28(1) .138-142$.

\section{Authors}

Natalia S. Sysoeva - Director, Vladimir Sukachev Irkutsk Regional Fine Arts Museum, Associate Professor, Head of the Irkutsk regional Branch of the "Union of Artists of Russia», 5 Lenin St., 664025, Irkutsk, the Russian Federation, e-mail: iohm@irk.ru.

Marina L. Tkacheva - PhD in Philosophy, Associate Professor, Department of Philosophy, Baikal State University, 11 Lenin St., 664003, Irkutsk, the Russian Federation, e-mail: margo514@yandex.ru.

\section{For citation}

Sysoeva N. S., Tkacheva M. L. Irkutsk Fine Arts Museum: Life in the City. Izvestiya Baykal'skogo gosudarstvennogo universiteta $=$ Bulletin of Baikal State University, 2018, vol. 28, no. 1, pp. 138-142. DOI: 10.17150/2500-2759.2018.28(1).138-142. (In Russian). 